\title{
AN OVERVIEW OF THE FOSSIL RECORD OF CLIMBERS: BEJUCOS, SOGAS, TREPADORAS, LIANAS, CIPÓS, AND VINES
}

\author{
ROBYN J. BURNHAM \\ Museum of Paleontology, University of Michigan 1109 Geddes Avenue, Ann Arbor, MI 48109-1079, USA. \\ rburnham@umich.edu
}

\begin{abstract}
One of the most obvious life forms in tropical forests today is the liana, which laces together tree canopies and climbs the dark interiors of forests with snake-like stems. Lianas are ecologically important in extant, forested ecosystems, both intact and disturbed. Their contribution to forest diversity, food resources, structural complexity, and plant-animal interactions are recognized, but rarely studied. Climbers (woody lianas and herbaceous vines) are viewed as everything from diversity contributors to forest growth inhibitors by modern ecologists and systematists. Climbers take advantage of the structural support of trees to invest proportionately more in vegetative and reproductive organs, resulting in proliferation at the individual and species level. Today the climbing habit is dominated by angiosperm species, with only a minor contribution from ferns plus a single non-angiosperm seed plant genus, Gnetum. This contribution reports the establishment of the newly established database, Fossil Record of Climbers (FRC) that documents more than 1100 records of climbing plants from the Paleozoic to the Quaternary using published literature on the fossil record. The diversity of climbers in the fossil record prior to the evolution of angiosperms is explored, posing the hypothesis that climbers of the past had a similarly important role in tropical forests, at least in the Paleozoic. The extinct Paleozoic pteridosperms, in particular, appear to have employed a range of morphologies and strategies as diverse as those of angiosperms today. The apparently small contribution of climbers to Mesozoic ecosystems, in contrast, may be a result of relatively few detailed morphological and anatomical studies capable of identifying fossil lianas, as well as unusually inhospitable conditions for growth and fossilization. The importance of climbers in ancient ecosystems is underlined to encourage greater recognition of life form diversity in the past.
\end{abstract}

Key words: Liana, vine, climbers, Paleozoic, Mesozoic, Cenozoic.

RESUMO - Uma das formas de vida mais comuns em florestas tropicais atuais são as lianas, as quais unem os dosséis das árvores e escalam os interiores escuros das florestas com ramos similares a cobras. Lianas são ecologicamente importantes em ecossistemas florestais intactos e em ecossistemas perturbados. Sua contribuição para a diversidade das florestas, recursos alimentares, complexidade estrutural, e interações planta-animal são reconhecidos, mas raramente estudados. Trepadeiras (lianas lenhosas e videiras herbáceas) são vistas por ecólogos e sistematas modernos como contribuintes da diversidade e como inibidores do crescimento da floresta. Trepadeiras aproveitam o apoio estrutural das árvores para investir proporcionalmente mais em órgãos vegetativos e reprodutivos, resultando na proliferação ao nível individual e específico. Na atualidade, o hábito de liana é dominado por espécies de angiospermas, contando apenas com uma pequena contribuição de samambaias e de um único gênero de plantas com sementes não-angiospermas, Gnetum. Este trabalho relata a criação de uma base de dados, o Registro Fóssil de Trepadeiras (RFT), a qual documenta mais de 1.100 citações de plantas trepadeiras do Paleozóico ao Quaternário, utilizando literatura publicada sobre o registro fossil. A diversidade das trepadeiras no registro do fóssil anterior à evolução das angiospermas é explorada, levantando a hipótese de que as trepadeiras do passado tiveram um papel similarmente importante nas florestas tropicais, pelo menos no Paleozoico. Em particular, as extintas Pteridospermas do Paleozóico parecem ter utilizado uma ampla gama de morfologias e estratégias tão diversas quanto as vistas nas angiospermas atuais. A aparente baixa contribuição das trepadeiras aos ecossistemas do Mesozoico, por outro lado, pode ser resultado de relativamente poucos estudos morfológicos e anatômicos detalhados capazes de identificar lianas fósseis, assim como condições particularmente inóspitas para o crescimento e fossilização. A importância das trepadeiras aos ecossistemas antigos é levantada de forma a incentivar o maior reconhecimento da diversidade de formas de vida no passado.

Palavras-chave: Liana, cipó, trepadeiras, Paleozóico, Mesozóico, Cenozóico.

\section{INTRODUCTION}

The role of climbers in extant ecosystems outstrips our knowledge of their biological characteristics, their distributions, or even their biological diversity. Recent reviews of the role of climbers in forest ecosystems (Putz \& Mooney, 1991; Schnitzer \& Bongers, 2002; Wright et al., 2004; Phillips et al., 2005) have highlighted the abundance, competitive 
abilities, and contribution to disturbance regimes. Today, climbing plants typically contribute $2-15 \%$ of the leaf biomass and about $5 \%$ of the wood biomass to forests (Fearnside et al., 1999; Gerwing \& Farias, 2000; Clark et al., 2008). In climber-rich areas they can contribute as much as $40 \%$ of the estimated total biomass (Hegarty \& Caballé, 1991; Perez-Salicrup et al., 2001).

Climbers (woody lianas and herbaceous vines) accomplish this balancing act, high vegetative biomass perched atop low woody biomass, through structural dependence on other upright organisms or structures. Through their structural parasitism, they are able to invest large amounts of photosynthetic products into vegetative growth, reproductive propagules, and continuously meristematic tissues. Compared to other upright growth habits, like trees and shrubs, climbers invest large amounts of photosynthetic products in woody structural tissues. For climbers, the potential for vegetative proliferation is thus high, leading to large and potentially isolated populations that may contribute to speciation if broad geographic distributions are dissected.

Recent concerns over forest fragmentation, abandoned agricultural lands, repeated timber harvesting, and increasing levels of carbon dioxide in the atmosphere have stimulated research on the relative response of climbers to these changes. As expected, climbers are able to respond more quickly and more intensely than trees to forest openings, disturbance, and increased $\mathrm{CO}_{2}$ (Schnitzer et al., 2000; Schnitzer \& Carson, 2001; Londre \& Schnitzer, 2006; Schnitzer \& Bongers, 2005; Mohan et al., 2006; Allen et al., 2007; Chen et al., 2008). So far, modern ecological research has not clearly identified the climber species or the morphological traits that are most advantageous under ecological perturbation.

The unique morphological innovations found in modern climbers include highly variable stem anatomy, many different climbing mechanisms, such as tendrilling or hooking, and a propensity for vegetative regeneration, as mentioned above. Stem tissues often include large amounts of parenchymatous cells, multiple cycles of vascular cambia that display varying degrees of continuous activity, multiple cables of vascular tissues, and extremely excentric programs of growth, creating unique stem anatomy collectively labelled anomalous growth (Carlquist, 1991). Climbing mechanisms include: (i) indeterminate apical stem twining, usually dextral (Burnham, unpubl. data); (ii) determinate tendrils produced by a variety of modified organs (axillary stems, inflorescences, modified leaves, portions of lateral branches); (iii) scrambling using hooks, spines, scabrous leaves or stems; and (iv) adventitious root adhesion. These mechanisms are reviewed and applied in Teramura et al., (1991), Putz \& Holbrook (1991), and Jongkind \& Hawthorne (2005). The variety and breadth of the morphological innovations found in plants employing a climbing habit, and the restriction of some innovations to one or a few lineages, are testament to the broad phylogenetic distribution of climbers within the angiosperms today.

Phylogenetically, climbers are found in over 125 families of flowering plants (Gentry, 1991) as well as among several fern groups (Smith et al., 2006), and even in one significant non-angiosperm seed-plant genus, Gnetum. Climbers represent $20-25 \%$ of the tall woody species in tropical forests (Gentry \& Dodson, 1987; Lott et al., 1987; Burnham et al., 2001; Bongers et al., 2002). They are found among ancestral groups of angiosperms such as the Piperales and Austrobaileyales, among monocotyledons (e.g., Dioscoreaceae, Arecaceae, and Araceae), and are commonly represented in both major groups of Rosids and both major groups of Asterids. This phylogenetic breadth strongly supports multiple origins of the climbing habit within angiosperms, and supports the idea that a significant advantage is conferred on plants that are able to transition from self-supporting to assisted-support. Within flowering plants alone, Caballé (1993) estimated that between 5,000 and 10,000 species of climbers exist today.

Climbing plants are thus ecologically important and evolutionarily diverse. They are a distinctive feature of modern tropical forested ecosystems (Croat, 1978; Gentry, 1991; Richards, 1996). In spite of this angiosperm-centered view of climbers, substantial evidence has accumulated, in isolated reports on the fossil record, of diverse climbers prior to the Cretaceous radiation of angiosperms. This contribution brings together those isolated reports in the database, Fossil Record of Climbers (FRC), which tabulates climbing plants from the Paleozoic to the Quaternary, using published literature from the fossil record. Using this database, I have attempted to provide preliminary answers to the following questions: (i) How long ago were climbing plants common in forested ecosystems? (ii) How species rich was the niche of ancient climbers? (iii) Did climbers play a role in ancient ecosystems equivalent to the role played in modern ecosystems? Are extant proportions of climbers similar to those of ancient forest communities? (iv) Before angiosperms dominated warm temperate and tropical forests, which plant groups included climbers? Which plant groups were dominant among climbers?

\section{METHODS}

\section{Defining a liana}

For this review of the fossil history of lianas, a liana is defined as a plant whose structural support does not come entirely from its own tissues, whose original rooting position was in the soil or a surface close to the soil, and whose climbing efforts may take its foliage and reproductive organs into the tree canopies. No distinction is made here between woody and herbaceous species: both herbaceous and woody "vines" are interchangeably called lianas or climbers here. In most censuses and reviews of the climbing habit, members of the angiospermous Araceae and Marcgraviaceae, as well as epiphytic ferns, are excluded (Romero-Saltos, 1999; Burnham, 2002; Parren et al., 2005). These extant groups include climbers whose roots are often found growing into the trunks of trees instead of in the soil, and whose habit is best characterized as epiphytic, rather than climbing. I have included fossil species of epiphytes here because these epiphytes, although not lianas in the strict sense of the definition, do utilize the support of other structurally- 
independent species to gain access to higher positions in a forest canopy, they form an axial stem-like structure that seeks a higher position in the canopy, and their inclusion may stimulate the tabulation of this life form separately in the future (see Dubuisson et al., 2009). Thus, for example, in the data analyzed and presented here I have included Paleozoic species of Botryopteris and some of Anykyropteris that may be technically classified as epiphytes. The absolute number of these potentially epiphytic plants is small and does not change the general picture portrayed here.

\section{Inferring the liana habit from the fossil record}

Because the fossil record normally provides us with fragmentary pieces of plants, rather than complete individuals, inference of plant habit is almost always made on a provisional basis. It is common for authors of new species, and even of some community reconstructions, to only cautiously offer insight into the habit of the plants reconstructed. The inferences drawn here are either those of the present author or inferred from the primary literature but do not necessarily reflect the opinion of the author of each inferred climber species. In other cases, entire clades have been proposed as climbers (e.g., lyginopterids: Cleal, 2008) and this may include some species whose life form was largely self-supporting, and yet those forms are not well enough known to exclude. In these cases, all are included when the greatest majority of species known are presumed to be climbing. To facilitate decisions on the habit of specific fossil plants, the criteria listed in Table 1 were used. The criteria on which the liana habit were based are noted for each fossil record in the available on-line database. The rationale and examples of the use of these characters, especially in combination, to indicate a climbing habit can be found in the literature cited.

\section{Assembling and coding species from the literature on fossil lianas}

Citations of liana habit in the fossil record were gleaned by systematic searches of the available published literature using all search engines, electronic databases (e.g., ISI Web of Science, JSTOR, Paleobiology Database, Google Scholar, etc.), and literature known to the author. Cataloguing and making corrections to the database is on-going and will continue as readers of this report and viewers of the on-line data base discover omissions and suggest corrections. Many references to angiosperm climbers are not yet entered, especially those from the palynological literature, where many pollen types have not been connected with source plants. In the future, a concerted effort will be made to improve (and expand) records throughout the database, in particular additions from the Quaternary, which has been left virtually empty at present. Angiosperms represent close to half of the records, and because of the potential artifact caused by the "pull of the recent" (Raup, 1979; but see Jablonski et al., 2003), it was deemed more useful for the questions posed here, to focus especially intently on the Mesozoic and Paleozoic records, rather than to fill in the myriad references to potential Paleocene through Quaternary fossil lianas.
Multiple references to the same species within a small geographic region and within the same time interval (see Table 3 ) were listed only once, to avoid multiple citations from the same stratigraphic level. 'Small geographic regions' were defined as single states within the United States, small countries within Europe, or halves of countries in larger European countries. This was a conservative approach, and I am aware that this strategy will result in time and spaceaveraged records to some degree. However, because the main goal was to determine the broad geographic, phylogenetic, and temporal coverage of the liana habit, the choice was made to downplay the geographic areas that might be heavily sampled and studied. When appropriate, multiple literature citations are included in a single fossil species record, all of which may cite the same specimens (generally in regional compendia), or may cite specimens from closely spaced localities.

Most of the climber record entries are at the species level. However, some determinations to genus only are entered (e.g., Archeampelos sp., Karinopteris sp.), if they are reported as a part of a review or flora in which specimens have been compared with other species from the same genus in the fossil record (e.g., McIver \& Basinger, 1999; Krings et al., 2003). This strategy, of excluding some published literature in which specimens are not identified to the species level (e.g. Le Page

Table 1. Characters used to diagnose climbing habit and supporting exemplar literature.

\begin{tabular}{|c|c|}
\hline Characters in climber & $\begin{array}{l}\text { Example and/or r ationale } \\
\text { reference }\end{array}$ \\
\hline Long internodes & $\begin{array}{l}\text { Ray, 1986; Galtier, 1988; Dubuisson } \\
\text { et al., 2003; Dunn et al., 2006; } \\
\text { DiMichele et al., } 2006\end{array}$ \\
\hline $\begin{array}{l}\text { Small s tem diameter to } \\
\text { length ratio }\end{array}$ & $\begin{array}{l}\text { Dunn et al.,2006; Harris et al., 2007; } \\
\text { Ichihashi et al., } 2009\end{array}$ \\
\hline $\begin{array}{l}\text { Small s tem diameter } \\
\text { relative to supported } \\
\text { foliage }\end{array}$ & Galtier, 1988; Selaya \& Anten, 2008 \\
\hline $\begin{array}{l}\text { Delayed apical foliage } \\
\text { expansion and/or dense } \\
\text { gl andular trichomes }\end{array}$ & $\begin{array}{l}\text { Baxter, 1949; He garty, 1991; Putz \& } \\
\text { Holbrook, 1991; Krings et al., 2003; } \\
\text { Ichihashi et al., } 2009\end{array}$ \\
\hline Adventitious roots & $\begin{array}{l}\text { Gen try, 1991; Hegarty, 1991; S peck, } \\
1994\end{array}$ \\
\hline $\begin{array}{l}\text { Large petiole bases } \\
\text { relative to stem diame ter }\end{array}$ & $\begin{array}{l}\text { Tomescu et al.,2001; Dunn et al., } \\
2006\end{array}$ \\
\hline $\begin{array}{l}\text { Hooks, spines, or } \\
\text { grappling structures }\end{array}$ & $\begin{array}{l}\text { Menninger, } 1970 ; \text { Hegarty, 1991; } \\
\text { Teramura et al.,1991 }\end{array}$ \\
\hline He te rophylly & $\begin{array}{l}\text { Baten bu rg, 1981; Lee \& Richards, } \\
\text { 1991; Kring s \& Kerp, 2000; Kring s et } \\
\text { al., 2001, } 2003\end{array}$ \\
\hline $\begin{array}{l}\text { Anomalous wood } \\
\text { anatomy: successive } \\
\text { cam bia; excessive } \\
\text { parenchyma; multiple } \\
\text { vas cular tis sue cycles }\end{array}$ & $\begin{array}{l}\text { Taylor \& Millay, 1981; Carlquist, } \\
\text { 1991; Ewers et al.,1991; Caballé, } \\
\text { 1993; Mosbrugger \& Roth, } 1996\end{array}$ \\
\hline $\begin{array}{l}\text { Structural anatomy } \\
\text { inconsistent with self- } \\
\text { support }\end{array}$ & $\begin{array}{l}\text { Li \& Taylor, 1998; Li et al., 1994; } \\
\text { Speck, } 1994\end{array}$ \\
\hline $\begin{array}{l}\text { Taxonomic affinities to } \\
\text { other climber taxa }\end{array}$ & Gianolli, 2004 \\
\hline $\begin{array}{l}\text { Direct observation of } \\
\text { clim ber w rapped on larger } \\
\text { individuals in "snapshot" } \\
\text { deposits }\end{array}$ & Oplustil et al., 2007, 2009 \\
\hline
\end{tabular}


et al., 2003), decreased the total number of records in the database but allows for broader geographic comparisons, which would otherwise not be valid with mixed taxonomic levels represented. That said, when species identities were not available, generic-only records are included for certain under-represented geographic regions.

In addition to organ(s) represented by the fossil citation, the type of preservation was also recorded to determine whether preservational status might influence interpretation of liana habit. One of three preservational states have been entered: Compression/Impression, Petrifaction/Coalball/ Wood, and Pollen. At the present time, finer subdivision of preservational state is not possible based on literature-only review, but future subdivision of the first two states is anticipated in the future.

Literature-based fossil records of the lianas are archived in an on-line database (available at http://wwwpersonal.umich.edu/ rburnham/), which is updated regularly, and thus may not correspond with the data presented here. The exact data presented here is also available at the above mentioned website, in static form, to facilitate reinterpretation, should that be desired. For each individual species from a locality that has been interpreted or can be interpreted as a liana, a single entry is made. Thus a widespread species, recognized from many localities, possibly from many stratigraphic levels may have multiple entries in the database. As mentioned above, multiple localities from the same stratigraphic level in a small geographic region (e.g., states in United States) are not listed as separate entries.

For each species record, the following information was scored and archived: Literature Citation, Higher Taxonomic Group, Genus, Species, Author, Organ(s) Represented, Preservation Type, Specific Locality and Region, Country or Province, Time Period, Subperiod, Evidence on which climber interpretation is based, Synonomies, Additional References (for sediment age, lithology, associated species, morphological features, repeated citations), Special Notes (including specifics on evidence, exceptions, disagreements on interpretation). An example of one of the more than 1100 records is provided in Table 2 .

\section{Caveat on database and methods}

A literature search and compilation has drawbacks in characterizing the fossil history of lianas: it will always be slightly out of date, incorporating specimens with suspect determinations, and lacking information, compared to the knowledge of individual investigators. In some cases, due to the lack of complete information, the database may include a species whose habit was no taller than a ground-level scrambler (e.g. Fragaria sp.): using nothing but the soil itself as a support, and never climbing $>0.5 \mathrm{~m}$ off the ground (thus an incorrect inclusion for this survey). These plants, in the view of almost all liana researchers should not be included in a classification of climbers, and yet they are difficult to exclude when evidence is fragmentary. In many cases, a species has been recorded as a climber because it belongs to a phylogenetic group that is or was almost entirely composed of climbers (e.g., family: Menispermaceae, or genus: Serjania) rather than on direct evidence of the climbing habit. Especially in the case of angiosperm species, the climbing habit is usually interpreted based on a modern close relative. In cases in which the modern closest relatives include a range of habits, from tree to shrub to liana (e.g. Ficus sp.), the assignment of a fossil taxon as a liana should be regarded cautiously, and has been done so here, usually excluded. Choices such as these were made because of the lack of additional evidence on the taxa in question. Geographic coverage of the database is currently limited by the available literature. There is an overrepresentation of studies carried out in Europe and North America. Corrections and additions to the on-line database are encouraged and requested.

Finally, for many disarticulated plants in the fossil record, several generic names have been applied before assembling the whole-plant reconstruction (e.g. Callistophyton). In some cases, more than one generic name has been entered for a single plant, potentially inflating the number of records. Again, as specialists have the opportunity to review the database, these kinds of reconstruction errors can be decreased, and yet at the same time the listing provided possibly can aid in the reconstruction of new climber species from their disarticulated parts.

\section{RESULTS}

A total of 1,175 individual instances of climbing plants from the fossil record were located and compiled for this publication. This number is substantially lower than the number potentially available, however the records give a good first picture of the fossil history of climbing plants. Although considerable effort was made to locate evidence from the Paleozoic and Mesozoic, with less effort placed on

Table 2. Information categories in Fossil Record of Climbers (FRC) database, with sample entry.

\begin{tabular}{|c|c|}
\hline Information Category & Sample Entry \\
\hline Literature Citation & $\begin{array}{l}\text { Kerp H. \& M. Krings } 1998 \text {. Climbing } \\
\text { and scrambling growth habits: } \\
\text { common life strategies among Late } \\
\text { Carboniferous seed ferns. C.R. } \\
\text { Acad. Sci. Paris de la Terre et des } \\
\text { Planetes 326:583-588. }\end{array}$ \\
\hline Higher Taxonomic Group & Mariopteridac eae (Pteridosperm) \\
\hline Genus, Species, Author & $\begin{array}{l}\text { Ps eudomariopteris cordato-ovata } \\
\text { (Weiss) Gillespie et al. }\end{array}$ \\
\hline Organ(s) Represented & leaf, cuticle \\
\hline $\begin{array}{l}\text { Specific Locality and } \\
\text { Region }\end{array}$ & Blanzy Montceau Bas in \\
\hline Country or Province & France \\
\hline Time Period, Subperiod & Carboniferous - Upper Stephanian \\
\hline $\begin{array}{l}\text { Evidence on which climber } \\
\text { interpretation is based }\end{array}$ & $\begin{array}{l}\text { bifurcating climber hooks from } \\
\text { pinnae and numerous small spines }\end{array}$ \\
\hline Synonomies & $\begin{array}{l}\text { Pseudomariopteris ribeyronii } \\
\text { (Zeiller) Danze-Corsin; } \\
\text { Diploptmemaby Zeiller; } \\
\text { Neuropteris earlier by Weiss } \\
\end{array}$ \\
\hline Additional References & Zeiller 1906; Krings \& Kerp 2000 \\
\hline Special Notes & $\begin{array}{l}5 \text { of } 23 \text { species are climbers at } \\
\text { Blanzy-Montceau }\end{array}$ \\
\hline
\end{tabular}


the many records from the Cenozoic, the database still includes 44\% (516/1175) of its records from the Cenozoic (Table 3). The Cenozoic record is strongly dominated by angiosperms $(90 \%$; 464/516) with only ferns accounting for the remainder. The Mesozoic record is astonishingly scant with only 73 records found cumulatively from the Triassic, Jurassic, and Cretaceous. The large majority of the Mesozoic records are Late Cretaceous climbers (71\%), which are largely angiosperm species.

\section{The Paleozoic record}

The Paleozoic climbing plant record, almost equal in record number to the Cenozoic, includes several major plant groups. Six broad phylogenetic groups are recognized among climbers during the Paleozoic: Sphenophyllales, Filicales, Lyginopteridales, Mariopteridales, Medullosales, Callistophytales, and (rarely) Gigantopteridales. The seed ferns represent the largest group, encompassing the Lyginopteridales, Medullosales, Mariopteridales, and Callistophytales, all entirely extinct. However, contribution by pteridophyte climbers is also significant (Table 3 ). Gigantopterids are included, but climbing habit in these plants is inferred from interpretations of high leaf biomass supported on thin stems, interpretations that have been made from incomplete material (Li \& Taylor, 1998, 1999; Wang, 1999; Rees, 2002), the clear demonstration of climbing hooks on some species strongly supports a habit that was not selfsupporting (Halle, 1929; Li \& Taylor 1998; Hilton et al., 2004). How long ago were climbing plants common in forested ecosystems? It is clear that climbing plants were abundant enough to be fossilized and subsequently recovered as early as the mid-Mississippian (Visean $~ 335 \mathrm{Myr}$ ). Several genera of lyginopterid pteridosperms (Lyginopteris, Rhetinangium, Sphenopteris) include species whose first appearance is in the mid to late Mississippian. Significantly they occur in similar-age sediments in deposits from the Czech Republic, Scotland, and Arkansas, U.S.A. In France and Scotland, remains of presumed climbing pteridophytes and pteridosperms are also found in Visean age sediments (Galtier et al., 1993). So, climbers were abundant and diverse even in the early Carboniferous.

How species rich was the niche of ancient climbers? A small amount of quantitative data exist to answer this question and the related, "Are extant proportions of climbers similar to those of ancient forest communities?" The data available on modern temperate and tropical forests, in which both abundance and taxonomic identification of lianas has been made, indicates that from $10-25 \%$ of the woody species are attributable to lianas, and $4-12 \%$ of the biomass is contributed by lianas (Putz, 1983; Fearnside et al., 1999; Allen et al., 2007; Clark et al., 2008; Phillips et al., 2008). Extremely climber-rich modern habitats have been reported with up to $40 \%$ species contribution by vines and lianas, but these appear to be outliers (Hegarty \& Caballé, 1991; Perez-Salizcrup et al., 2001).

The Paleozoic record indicates that there was structural modernization very early, that is, plant habits in similar proportions to communities of today. As early as the Mississippian, species lists of relatively completely studied paleofloras preserved as compressions or impressions in siliclastic rocks (as opposed to coal beds) (e.g. Fayetteville: Dunn, 2004; Dunn et al., 2006) include up to $50 \%$ (8 of 15) of the reconstructed taxa as climbers (or epiphytes). In contrast,

Table 3. Distribution of records in Fossil Record of Climbers (FRC) database by geologic age. Time periods "bins" are not of equivalent time duration.

\begin{tabular}{|c|c|c|c|c|c|c|c|c|c|c|c|}
\hline & $\begin{array}{l}\frac{1}{<} \\
\stackrel{\circ}{\circ}\end{array}$ & $\begin{array}{l}\frac{0}{0} \\
\frac{0}{2} \\
\frac{0}{0} \\
\frac{0}{0} \\
\Phi \\
\frac{0}{0} \\
\dot{0}\end{array}$ & 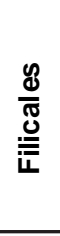 & 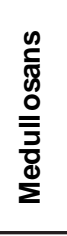 & 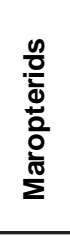 & 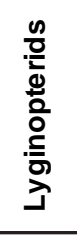 & 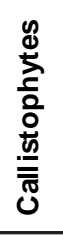 & 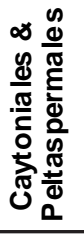 & $\begin{array}{l}\frac{0}{0} \\
\frac{0}{\bar{d}} \\
\frac{0}{0} \\
\frac{0}{0} \\
\frac{0}{5} \\
\frac{8}{0}\end{array}$ & 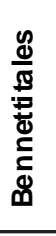 & $\begin{array}{l}\stackrel{0}{\xi} \\
\frac{5}{\Phi} \\
\frac{0}{0} \\
\frac{0}{5} \\
\frac{5}{4}\end{array}$ \\
\hline Mississippian & 49 & 0 & 5 & 2 & 3 & 39 & 0 & 0 & 0 & 0 & 0 \\
\hline Pennsylvanian & 488 & 44 & 79 & 67 & 113 & 169 & 16 & 0 & 0 & 0 & 0 \\
\hline Early Permian & 42 & 11 & 13 & 2 & 2 & 4 & 5 & 0 & 5 & 0 & 0 \\
\hline Late Permian & 16 & 3 & 2 & 0 & 0 & 0 & 0 & 0 & 11 & 0 & 0 \\
\hline Early Triassic & 1 & 0 & 0 & 0 & 0 & 0 & 0 & 1 & 0 & 0 & 0 \\
\hline Late Triassic & 9 & 0 & 0 & 4 & 0 & 0 & 0 & 1 & 0 & 4 & 0 \\
\hline Jurassic & 1 & 0 & 1 & 0 & 0 & 0 & 0 & 0 & 0 & 0 & 0 \\
\hline Early Cretaceous & 10 & 0 & 5 & 0 & 0 & 0 & 0 & 0 & 0 & 0 & 5 \\
\hline Late Cretaceous & 52 & 0 & 5 & 0 & 0 & 0 & 0 & 0 & 0 & 0 & 47 \\
\hline Paleocene & 42 & 0 & 3 & 0 & 0 & 0 & 0 & 0 & 0 & 0 & 39 \\
\hline Eocene & 249 & 0 & 23 & 0 & 0 & 0 & 0 & 0 & 0 & 0 & 226 \\
\hline Oligocene & 41 & 0 & 6 & 0 & 0 & 0 & 0 & 0 & 0 & 0 & 35 \\
\hline Miocene & 117 & 0 & 9 & 0 & 0 & 0 & 0 & 0 & 0 & 0 & 108 \\
\hline Pliocene & 45 & 0 & 2 & 0 & 0 & 0 & 0 & 0 & 0 & 0 & 43 \\
\hline Quaternary & 13 & 0 & 0 & 0 & 0 & 0 & 0 & 0 & 0 & 0 & 13 \\
\hline
\end{tabular}


permineralized swamp floras, preserved as petrifactions within coal beds, from both the Mississippian and the Pennsylvanian (Dunn et al., 2006; Wing \& DiMichele, 1995) included few obviously climbing taxa: 1-2 of 15-20 species, yet still this represents $5-10 \%$ of the species richness. In clastic environments of the Czech Republic, Oplustil et al. (2007) recorded the plant habit of each species in several separate coal sections. There, they report a remarkably consistent proportion of climber species through the coals: from 13$23 \%$, which overlaps with modern angiospermous liana species proportions in tropical and temperate forests. The values recorded from Oplustil et al. (2007) are minimum proportions because the species coded as "unknown or vines" are excluded. Clearly the Paleozoic record is one of strong habitat differences in species richness (DiMichele et al., 2006), but the variation is on the order of the variation among modern ecosystems.

Biomass and frequency of Paleozoic climbers: Did climbers play a role in ancient ecosystems equivalent to the role played in modern ecosystems? Quantitative estimates of biomass from the fossil record, based on abundances in peat accumulation in the Pennsylvanian, indicate that typical contributions by climbers are from 1.5 to $11 \%$ (e.g., DiMichele \& Phillips, 1996). In data generated by point counting (ratio data), Phillips (1981) reports that the single genus Callistophyton, a Pennsylvanian climber, contributed as much as $16 \%$ of the cover in coal ball zones in southern Illinois, U.S.A. In other pteridosperm-dominated peats, the biomass volume estimate is as high as $94 \%$ for climbing pteridosperms, a situation in which the preserved tangle of fossil stems and leaves is almost completely Lyginopteris sp. (Phillips, 1981). Gastaldo et al. (2004) found similar lyginopterid dominance in shale sediments preserving a single time horizon. In European coal balls, Galtier (1997) reported that lyginopterids are present in more than $30 \%$ of all coal balls in some regions (Katharina-Germany, Union and Upper Foot-England), and yet in as few as $4 \%$ in others (Bouxharmont-Belgium). Because the fragments are small, the biomass in these same deposits is estimated as small, only $2 \%$ (Phillips, 1981). Some of the fossil data are representative of very wet swamp environments, a habitat in which modern liana abundance and diversity are not particularly high (R.J. Burnham, unpublished data). With that in mind, these relatively high proportions of Paleozoic liana species and abundances are remarkable, and may be quite distinct from low nutrient, high water-table environments today.

Paleozoic phylogenetic diversity and comparison to extant climbers. Before angiosperms dominated warm temperate and tropical forests, which plant groups included climbers? Which plant groups were dominant among climbers?

Phylogenetic diversity among climbers of the Paleozoic was much broader than the phylogenetic diversity of climbers on earth today, if we assume that each lineage of seed-bearing and free-sporing plant represents an equivalent entity. The pattern of decreasing phylogenetic diversity by removal of many different groups of extinct seed plants is generally true for all plant habits, not just climbers, and has been known for many years (Niklas et al., 1983, 1985; DiMichele et al., 2001; Rees, 2002; Willis \& McElwain, 2002). In contrast, the only major land plant lineages that contribute substantially to modern climber communities are pteridophytes and angiosperms (Figure 1). Today angiosperms comprise close to $90 \%$ of land plant diversity (Crepet \& Niklas, 2009). In contrast, the Paleozoic record, and especially the Pennsylvanian, includes sphenophylls, filicaleans, and four major subgroups of pteridosperms. The spectacular diversity of growth forms within the extinct pteridosperms includes ground covers, epiphytes, shrubs, vines, scramblers, and forest trees (Krings et al., 2003; DiMichele et al., 2006). In particular, lyginopterid pteridosperms have been characterized (Taylor \& Millay, 1981; DiMichele et al., 2006; Cleal, 2008; Taylor et al., 2009) as representing almost exclusively climbers (vines, scramblers, lianas). The Paleozoic climbing community also included a variety of sphenophylls, whose main mechanism of climbing was by climber hook extensions on foliage and stem axes (Bashforth \& Zodrow, 2007). Filicalean ferns, in a variety of forms, also contributed to the climber community, and are perhaps under-appreciated in their ability to participate consistently as a climber growth form starting in the Mississippian and extending to the present.

\section{The Mesozoic record}

The Mesozoic record is currently poorly known for climbers, but the indications are that a dramatic decline in climber abundance and diversity had occurred by the end of the Permian, leaving little biodiversity or biomass in the climber life form/guild at the start of the Mesozoic. During the Triassic and Jurassic almost no unambiguous reports of climbers were found (Figure 1, Table 3). A few species of the following genera have been suggested as climbers but little has been offered in direct evidence: Lepidopteris, Rhexoxylon, Eoginkgoites, and Stachypteris (Walton, 1923; Ash, 1976; McElwain et al., 2007). The early and middle Mesozoic portion of the record includes a few bennetittaleans, some questionable reports of Rhexoxylon (a late occurring medullosalean), and a handful of ferns. The only significant number of climber records is attributed to angiosperms in the Cretaceous. It is during the Mesozoic that intense focus on life forms among glossopterids, callipterids, other peltasperms, and corystosperms just might clarify the decline among climbers. In addition, more work on the life habits of the many ferns known from the Mesozoic may fill this gap in the record (Skog, 2001).

\section{The Cenozoic record}

As mentioned earlier, there are many records to add to the current FRC database, and some records entered should be reevaluated as more detailed analyses are made of the species named in the last century. However, the species 
richness of climbers appears to be high throughout the Cenozoic, even if the phylogenetic diversity is restricted to ferns and angiosperms. In tropical floras, the identity of some climbers may still be unclear, while in temperate regions many entries are of familiar genera that climb today: Smilax, Vitis, Dioscorea, etc. Many entries from the Menispermaceae and Icacinaceae are presumed to be indicative of subtropical to tropical climates, while species in the genus Ficus have been entirely excluded because of the difficulty of assigning any of the fossil species to life habit. In tropical Cenozoic paleofloras, we should expect a high proportion of angiosperm climbers derived from streamside and disturbed habitats where they are in high abundance today (Burnham et al., 2001).

\section{Climber geography}

Our current knowledge of the geographic range and relative abundance of extinct climber species is limited. A few common Paleozoic species are known to have been widespread, occurring from North America to Western and Eastern Europe (e.g., Lyginopteris oldhamia, Pseudomariopteris busquetti, and Sphenophyllum oblongifolium: Gillespie \& Pfefferkorn, 1979; Phillips, 1981; Masselter et al., 2006), but the majority of forms are known from only a few occurrences, even though they may be locally abundant. The Cenozoic record includes many widespread genera (e.g., Vitis, Lygodium), but the vast majority of species are known from only a few localities or stratigraphic levels. As contributions accumulate in the actively updated database on the Fossil Record of Climbers (FRC), we should be able to improve the outlines of geographic coverage and species abundance.

\section{Climbing mechanism}

In the Paleozoic, evidence of climbing mechanisms such as adventitious roots, tendrils, and spiney hooks is abundant (Krings et al., 2003). The climbing mechanism of any fossil species is difficult to determine, in particular the inference of apical stem twiners (Krings et al., 2003). Even so, species with narrow, somewhat flattened stems and long internodes are good candidates for apical stem twiners, a climbing mechanism shared by about $60 \%$ of tropical liana species today (Burnham, unpubl. data). These characteristics, in combination with attributes typical of vine morphology (see Table 1), should help flag species whose life form is as yet unknown. The Mesozoic record analyzed so far has virtually no direct evidence of climbing mechanism preserved. Similarly, the Cenozoic record has, thus far, revealed few instances where climbing mechanism can be observed directly. The presence of modern genera that today include only a single type of climbing mechanism allows strong inference that the same mechanism found in the extant genus also was present in the fossil species. Clearly, well resolved phylogenetic trees for climber families and genera would bolster this inference. Practically speaking, the basis of the fossil generic determination is often leaf morphology for the Cenozoic compression-impression fossil records. Direct evidence of isolated tendrils is found in angiosperm floras in low numbers (e.g., Chalk Bluffs, Buckeye florule: Erwin, 2006), but is not normally associated with particular taxa.

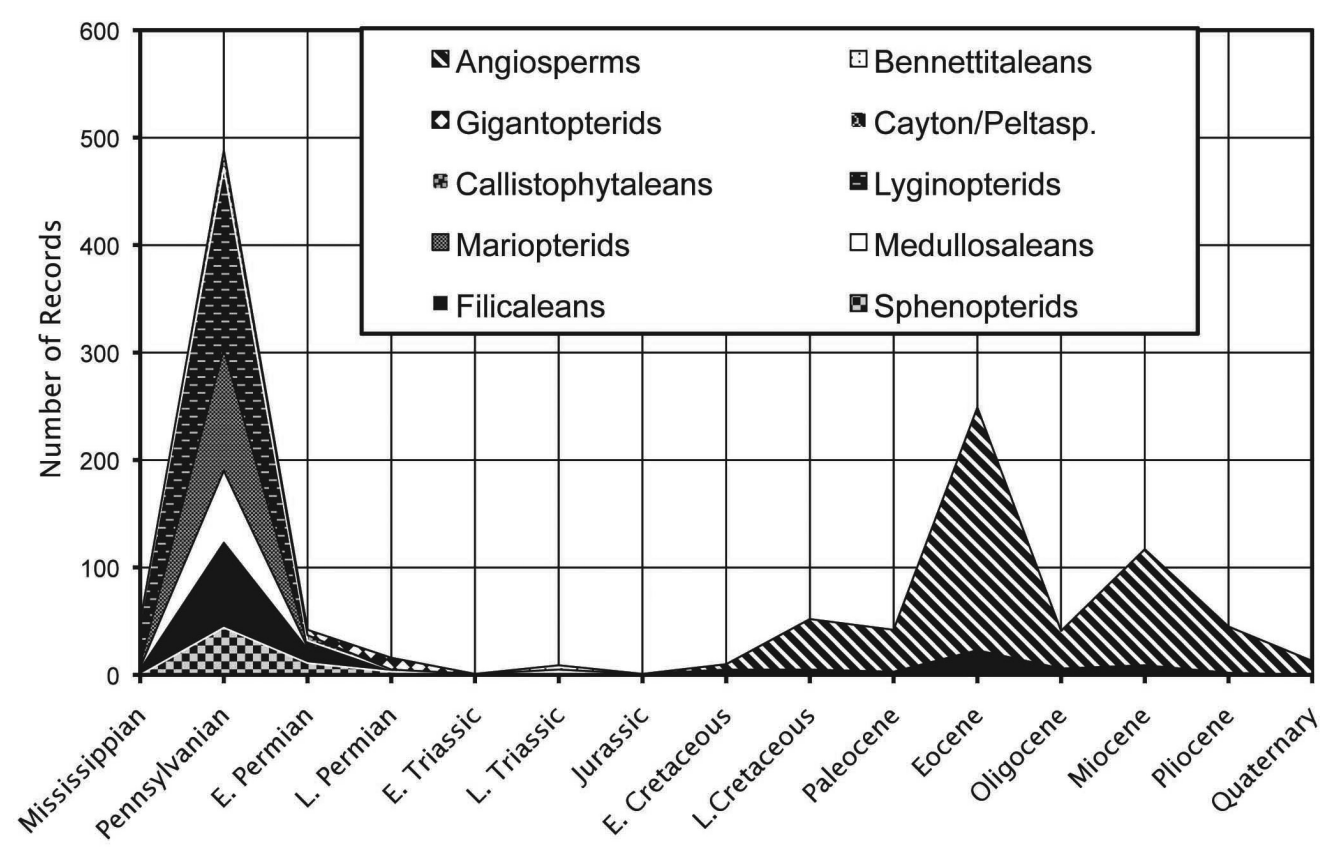

Figure 1. Record numbers of published climber occurrences from the Mississippian through the Quaternary. Most of the palynological and Quaternary literature is not entered here. For number of each groups depicted, see Table 3. High numbers of records for the Paleozoic and Cenozoic are in stark contrast to the published Mesozoic climber record. 


\section{DISCUSSION}

The Fossil Record of Climbers (FRC) database, although still including a small fraction of all fossil climbers, shows a pattern of abundance and diversity that begins in the Early Carboniferous with surprising phylogenetic breadth. A few records from most of the major plant groups are present (excluding calamites and isoetaleans, for example), expanding to several genera and species in each major group by the Pennsylvanian (Figure 1). The intense spike of diversity and abundance is a combination of species of sphenophylls, ferns, and pteridosperms of many lineages. The decline in climber diversity in the Late Permian, along with other plant life forms typical of the Pennsylvanian, is as dramatic as the earlier increase. While any change in the fossil record of diversity may be correlated with the available outcrop area, paleogeography, and the proximity of outcrops to major longstanding paleontological research institutions (Rees, 2002; Burnham, 2008), the pattern is not likely to be wholly artifactual (DiMichele \& Aronson, 1992; Gastaldo et al., 1996). From the Late Permian right into and including the Early Cretaceous, the record is surprisingly sparse (only 37 records as of this publication), despite abundant literature on the Mesozoic fossil record of the largely gymnosperm-dominated ecosystems of this period (e.g. Wang, 2002; Hilton et al., 2004; McElwain et al., 2007).

A gradual increase in diversity in the Late Cretaceous leads to a precipitous increase in records in the Eocene, representing the angiosperm domination of both temperate and tropical ecosystems. The increase is not entirely accurate in its relative magnitude, because the number of records entered from the Eocene is much larger than for other epochs of the Cenozoic. Quaternary records have yet to be entered in full, but will be added in the near future. Further, there are many records from the Cenozoic that are based on determinations that should be reevaluated in light of modern methods of assessing angiosperm fossil-leaf identities (Ellis et al., 2009). Still, the contrast is striking between the early domination of Paleozoic ecosystems by a wide variety of plant groups, and the Cenozoic domination largely by angiosperms. The Paleozoic climbing niche was especially well exploited by seed ferns, particularly mariopterids and lyginopterids (Kerp \& Krings, 1998; DiMichele et al., 2006; Cleal, 2008), but ferns and sphenophylls also played a very important role. In contrast, only angiosperms today can be considered to be a wildly successful climber clade. The variation in angiosperm climber stem anatomies, climbing mechanisms, and modes of growth are reminiscent of the diversity in the Paleozoic climbers. Few remnants of that earlier diversity remain today, as only a few species of climbers are found among most extant land plant lineages.

Preservational state strongly influences our ability to recognize a disarticulated plant as a climber. Compressionimpression fossils normally cannot reflect details of the internal anatomy, which is often modified for efficient water translocation in lianas (Carlquist, 1988, 1991). Petrifactions can demonstrate these anatomical modifications, but will not reveal any details of hook, spine, or tendrilling mechanisms that can be more readily noted in compression-impression material, especially where cuticle is preserved (Kerp \& Krings, 1998, Krings et al., 2003). When cuticular analysis has linked disarticulated organs, great strides have been made in whole plant reconstructions. These types of analyses are very rare in Mesozoic fossil studies, in part because of preservational quality and in part because of limited exposures. Pollen morphology has no clear correlation to whole-plant liana morphology.

The database was evaluated for a systematic temporal bias in preservational state of the records, particularly with respect to preservational states that bear anatomical detail (petrifaction, coalball, wood) versus those with external morphology preserved (compression-impression). The results are shown in Figure 2. Compression-impression material shows no strong temporal trend. For time periods including at least 20 records, compression-impression material constitutes from 30 to $80 \%$ of all records per time period. The substantial contribution of coalballs and petrifactions in the Carboniferous are replaced by silicified seeds, fruits, and wood in the Cenozoic, all of which are coded as Petrifaction/ Coalball/Wood. So no trend can be detected, in spite of the phenomenal anatomical work that has been mostly restricted to coal balls during the Paleozoic. Each epoch of the Mesozoic include so few records that interpretation should be made cautiously at this point. That said, the proportion of compression-impression records ranges from 55 to $100 \%$ in the five poorly represented time periods from Late Permian to Early Cretaceous. Kerp (2000) remarked that aside from fossilized wood, no permineralized material is known from the Upper Permian and Triassic. This suggests that the lack of anatomical detail from petrifactions in addition to the lack

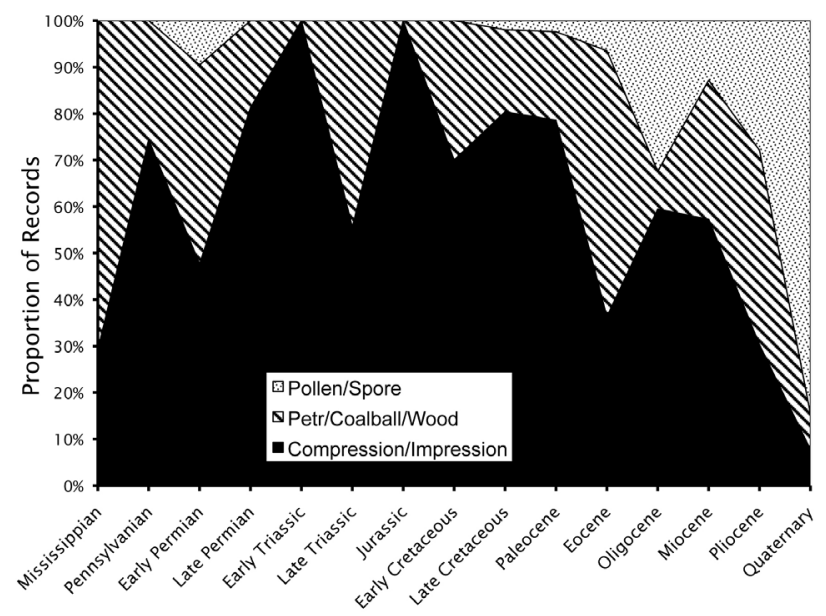

Figure 2. Preservational types of climber records from the Mississippian through the Quaternary. All records were categorized as belonging to one of the three types: Petrifaction/Coalball/Wood, Compression/Impression, or Pollen/Spores. No temporal trend can be demonstrated, however the record-poor period from Late Permian to Early Cretaceous has a consistently higher proportion of compression-impression records than petrifaction records Pollen/Spore records were not emphasized in accumulating records and should be considered provisional. 
of cuticular evidence from compressions may strongly contribute to the pattern recorded.

The virtual absence of climbers in the Mesozoic and latest Paleozoic is expected, given the relatively smaller number of well-studied outcrops, and yet surprising, considering the wide variety of plant groups documented as capable of assuming the climbing habit. I suggest that the pattern may, in fact, be reflective of the actual range of plant habits during this transition period from a fern and seed-fern dominated ecosystems to modern angiosperm dominated ecosystems. Conifers and cycadeoid gymnosperms did not radiate into the climber habit readily, in effect leaving the field open for pteridophyte (fern) climbers during this period. At the same time, vegetation appears to have undergone substantial structural changes at the Permian-Triassic boundary with a shift from conifer to lycopod dominated forests (Looy et al., 1999). This period of change throughout the early Mesozoic was detailed by Kerp (2000) who also acknowledged the scarcity of well-studied fossil floras. As more work is carried out on Permian and Mesozoic plant and ecosystem reconstructions we should be able to fill in some of the habit gaps, but probably not all. Once angiosperm lianas appeared and exploited the upright scaffold of both gymnospermous and angiosperm trees, their rapid growth and rapid reproduction took over the role of climbers. This suggests a series of very clear questions that can be posed using indepth knowledge of Mesozoic fossil localities: Are there means to recognize the climbers of the Mesozoic that we are not currently using? Did the climber niche remain virtually empty for 60 Myr of the Mesozoic? Did groups like cycads, conifers, and benetittaleans ever explore this life form? Can the climber habit be considered an open niche for a period of time in terrestrial ecosystems? What environmental conditions in the Mesozoic terrestrial realm might have rendered the climbing habit more problematic (McElwain et al., 2005)? Should we expect climbers to be some of the earliest life forms among angiosperms?

\section{CONCLUSIONS}

Climbing plants were important in Paleozoic forests as early as the Pennsylvanian (ca. $315 \mathrm{Myr}$ ), and possibly even earlier, although their ecological abundance is still unclear (Galtier, 1997; Dunn et al., 2006). The first climbing plants were present as soon as upright supports (trees) were present to climb upon. Climber species evolved within sphenophylls, filicaleans, and pteridosperms, and in each group many species can be documented as climbing, indicating that ancient climbers were, in fact, quite diverse. Although quantitative data on species richness are difficult to compare with that from modern forested communities, it appears that following the high Carboniferous diversity, a period of scarcity existed in the climber community, in species and in individuals. The Mesozoic low species diversity and abundance of climbers stands in stark contrast to the preceding Paleozoic, and subsequent Cenozoic. Warm temperate and tropical ecosystems of the Cenozoic appear similar in diversity and composition to modern climber communities.

Because climbers are present in so many ecosystems today, the morphological characteristics of the climber communities in disturbed versus stable, wetland versus welldrained, and open versus shaded forest ecosystems should help us recreate the distribution and importance of climbers in ecosystems throughout the last 300 million years.

\section{ACKNOWLEDGMENTS}

Sincere appreciation goes to my colleagues S. Ash, W. A. DiMichele, H. Kerp, M. Krings, S. Manchester, J. McElwain, S. Oplustil, K. Pigg, R. Rossler, N. Rowe, T. Speck, D. Tidwell, and many others who have provided images, insight, and valuable advice. Lucia Lohmann kindly edited the Portuguese abstract. Literature searching was aided by undergraduate research assistants R. Sonday and B.H. Sisson. Review of earlier versions of the manuscript by W. A. DiMichele, P. Foster, J. McElwain, and S. Y. Smith were instrumental to creating a coherent article for this publication.

\section{REFERENCES}

Allen, B.P.; Sharitz, R.R. \& P.C. Goebel 2007. Are lianas increasing in importance in temperate floodplain forests in the southeastern United States? Forest Ecology and Management, 242:17-23.

Ash, S. 1976. The systematic position of Eoginkgoites. American Journal of Botany, 63:1326-1331.

Bashforth, A.R. \& Zodrow, E. L. 2007. Partial reconstruction and palaeoecology of Sphenophyllum costae (Middle Pennsylvanian, Nova Scotia, Canada). Bulletin of Geosciences, Czech Geological Survey, 82(4):365-382.

Batenburg, L.H. 1981. Vegetative anatomy and ecology of Sphenophyllum zwickaviense, S. emarginatum, and other "compression species" of Sphenophyllum. Review of Palaeobotany and Palynology, 32:275-313.

Baxter, R.W. 1949. Some pteridosperm stems and fructifications with particular reference to the Medullosae. Annals of the Missouri Botanical Garden, 36(3):287-353.

Bongers, F.; S.A. Schnitzer \& D. Traore 2002. The importance of lianas and consequences for forest management in West Africa. Bioterre, Special issue:59-70.

Burnham, R.J. 2002. Dominance diversity and distribution of lianas in Yasuní, Ecudaor: who is on top? Journal of Tropical Ecology, 18:845-864.

Burnham, R.J. 2008. Hide and go seek: what does presence mean in the fossil record? Annals of the Missouri Botanical Garden, 95:51-71.

Burnham, R.J.; N.C.A. Pitman; K.R. Johnson \& P. Wilf 2001. Habitat-related error in estimating temperatures from leaf margins in a humid tropical forest. American Journal of Botany, 88(6): 1096-1102.

Caballé, G. 1993. Liana structure, function and selection: a comparative study of xylem cylinders of tropical rainforest species in Africa and America. Botanical Journal of the Linnean Society, 113:41-60.

Carlquist, S. 1988. Comparative wood anatomy: systematic, ecological, and evolutionary aspects of dicotyledon wood. New York, Springer-Verlag, $436 \mathrm{p}$. 
Carlquist S. 1991. Anatomy of vine and liana stems: a review and synthesis. In: F.E. Putz, \& H. A. Mooney (eds.) The biology of vines, Cambridge University Press, p. 53-72.

Chen, Y.-J.; Bongers, F.; Cao, K.-F. \& Cai, Z.-Q. 2008. Above- and below-ground competition in high and low irradiance: tree seedling responses to a competing liana Byttneria grandifolia. Journal of Tropical Ecology, 24:517-524.

Clark, D.B.; Olivas, P.C.; Oberbauer, S.F.; Clark, D.A. \& Ryan, M.G. 2008. First direct landscape-scale measurement of tropical rain forest leaf area index, a key driver of global primary productivity. Ecology Letters, 11:163-172.

Cleal, C.J. 2008. Palaeofloristics of Middle Pennsylvanian lyginopteridaleans in Variscan Euramerica. Palaeogeography, Palaeoclimatology, Palaeoecology, 261(1/2):1-14.

Crepet, W.L. \& Niklas, K.J. 2009. Darwin's second “abominable mystery": why are there so many angiosperm species? American Journal of Botany, 96(1):366-81.

Croat, T. 1978. Flora of Barro Colorado Island. Stanford, Stanford University Press, 943 p.

DiMichele, W.A. \& Aronson, R.B. 1992. The PennsylvanianPermian vegetational transition: a terrestrial analogue to the onshore-offshore hypothesis. Evolution, 46(3):807-824.

DiMichele, W.A. \& Phillips, T.L. 1996. Clades, ecological amplitudes, and ecomorphs: Phylogenetic effects and persistence of primitive plant communities in the Pennsylvanian-age tropical wetlands. Palaeogeography, Palaeoclimatology, Palaeoecology, 127:83-105.

DiMichele, W.A.; Stein, W.E. \& Bateman, R.M. 2001. Ecological sorting of vascular plant classes during the Paleozoic evolutionary radiation. In: W.D. Allmon \& D.J. Bottjer (eds.) 2001. Evolutionary paleoecology: the ecological context of macroevolutionary change, Columbia University Press, p. 285335.

DiMichele, W.A.; Phillips, T.L. \& Pfefferkorn, H.W. 2006. Paleoecology of late Paleozoic pteridosperms from tropical Euramerica. Journal of the Torrey Botanical Society, 133(1):83118.

Dubuisson, J.-Y.; Hennequin, S.; Rakotondrainibe, F. \& Schneider, H. 2003. Ecological diversity and adaptive tendencies in the tropical fern Trichomanes L. (Hymenophyllaceae) with special reference to climbing and epiphytic habits. Botanical Journal of the Linnean Society, 142(1):41-63.

Dubuisson, J.-Y.; Schneider, H. \& Hennequin, S. 2009. Epiphytism in ferns: diversity and history. Comptes Rendus Biologies, 332: $120-128$.

Dunn, M.T. 2004. The Fayetteville flora I: Upper Mississippian (middle Chesterian/ lower Namurian A) plant assemblages of permineralized and compression remains from Arkansas, USA. Review of Palaeobotany and Palynology, 132(1/2):79-102.

Dunn, M.T.; Mapes, G. \& Rothwell, G.W. 2006. The Fayetteville flora of Arkansas (USA): a snapshot of terrestrial vegetation patterns within a clastic swamp at Late Mississippian time. Geological Society of America, Special Paper, 399:127-137.

Ellis, B.; Daly, D.; Hickey, L.; Johnson, K.; Mitchell, J.; Wilf, P. \& Wing, S. 2009. Manual of Leaf Architecture. Ithaca, Cornell University Press, 190 p.

Erwin, D. 2006. Paleobotany field trip to the Sierra Nevada, field trips notes from BSA field trip, 2006, available at http:// www.ucmp.berkeley.edu/science/profiles/erwin_0609.php

Ewers, F.W.; Fisher, J.B.; \& Fichtner, K. 1991. Water flux and xylem structure in vines. In: F.E. Putz \& H.A. Mooney (eds) The biology of vines, Cambridge University Press, p. 127-160.
Fearnside, P.M.; Graça, P.M.L.A.; Leal Filho, N.; Rodrigues, F.J.A. \& Robinson, J. M. 1999. Tropical forest burning in Brazilian Amazonia: measurements of biomass loading, burning efficiency and charcoal formation at Altamira, Pará. Forest Ecology and Management, 123(1):65-79.

Galtier, J. 1988. Morphology and Phylogenetic relationships of early Pteridosperms. In: C.B. Beck (ed.) Origin and Evolution of Gymnosperms, Columbia University Press, p. 135-176.

Galtier, J. 1997. Coal-ball floras of the Namurian-Westphalian of Europe. Review of Palaeobotany and Palynology, 95:51-72.

Galtier, J.; Brown, R.E.; Scott, A.C.; Rex, G.M. \& Rowe, N.P. 1993. A late Dinantian flora from Weaklaw, East Lothian, Scotland. Special Papers in Palaeontology, 49:57-74.

Gastaldo, R.A.; DiMichele, W.A. \& Pfefferkorn, H.W. 1996. Out of the icehouse into the greenhouse: a Late Paleozoic analog for modern global vegetational change. GSA Today, 6(10):1-7.

Gastaldo, R.A.; Stevanovic-Walls, I.M.; Ware, W.N. \& Greb, S.F. 2004. Community heterogeneity of Early Pennsylvanian peat mires. Geology, 32(8):693-696.

Gentry, A.H. 1991. The distribution and evolution of climbing plants. In: F.E. Putz \& H.A. Mooney (eds.) The biology of vines, Cambridge University Press, p. 3-49.

Gentry, A.H. \& Dodson, C. 1987. Contribution of nontrees to species richness of a tropical rain forest. Biotropica, 19:149 156.

Gerwing, J.J. \& Farias, D.L. 2000. Integrating liana abundance and forest stature into an estimate of total aboveground biomass for an eastern Amazonian forest. Journal of Tropical Ecology, 16:327-335.

Gianoli, E. 2004. Evolution of a climbing habit promotes diversification in flowering plants. Proceedings of the Royal Society B: Biological Sciences, 271(1552):2011-2015.

Gillespie, W.H. \& Pfefferkorn, H.W. 1979. Distribution of commonly occurring plant megafossils in the proposed Pennsylvanian system stratotype. In: INTERNATIONAL CARBONIFEROUS CONGRESS, 9, 1979. Guidebook Series, vol. 1, Washington DC, American Geological Institute, p. 87-94.

Halle, T.G. 1929. On the habit of Gigantopteris. Geologiska Foreningens I Stockholm Forhandlingar, 51:236-242.

Harris, C.; Murray, B.R.; Hose, G.C. \& Hamilton, M.A. 2007. Introduction history and invasion success in exotic vines introduced to Australia. Diversity and Distributions, 13:467-475.

Hegarty, E.E. 1991. Vine-host interactions. In: F.E. Putz, \& H.A. Mooney (eds.) The biology of vines, Cambridge University Press, p. 357-375.

Hegarty, E.E. \& Caballé, G. 1991. Distribution and abundance of vines in forest communities. In: F.E. Putz, \& H.A. Mooney (eds.) The biology of vines, Cambridge University Press, p. 313-335.

Hilton, J.; Wang, S.-J.; Galtier, J.; Glasspool, I. \& Steven, L. 2004. An Upper Permian permineralized plant assemblage in volcaniclastic tuffs from the Xuanwei Formation, Guizhou Province, China. Geological Magazine, 114:661-674.

Ichihashi, R.; Nagashima, H. \& Tateno, M. 2009. Morphological differentiation of current-year shoots of deciduous and evergreen lianas in temperate forests in Japan. Ecological Research, 24(2):393-403.

Jablonski, D.; Roy, K.; Valentine, J.W.; Price, R.M. \& Anderson, P. 2003. The impact of the pull of the recent on the history of marine diversity. Science, 300:1133-1135.

Jongkind, C.C.H. \& Hawthorne, W.D. 2005. A botanical synopsis of the lianes and other forest climbers. In: F. Bongers; M.P.E. 
Parren \& D. Traoré (eds.) Forest Climbing Plants of West Africa: Diversity Ecology and Management, CABI Publishing, p. 1939.

Kerp, H. \& Krings, M. 1998. Climbing and scrambling growth habits: common life strategies among Late Carboniferous seed ferns. Comptes Rendus de l'Academie de Sciences, Ser. 2A, 326:583-588.

Krings, M. \& Kerp, H. 2000. A contribution to the knowledge of pteridosperm genera Pseudomariopteris Danzé-Corsin nov. emend. and Helenopteris nov. gen. Review of Palaeobotany and Palynology, 111:145-195.

Krings, M.; Kerp, H.; Taylor, T.N. \& Taylor, E.L. 2001. Reconstruction of Pseudomariopteris busquetti, a vine-like Late Carboniferous-Early Permian pteridosperm. American Journal of Botany, 88(5):767-776.

Krings, M.; Kerp, H.; Taylor, T.N. \& Taylor, E.L. 2003. How Paleozoic vines and lianas got off the ground: on scrambling and climbing Carboniferous Early Permian Pteridosperms. The Botanical Review, 69(2):204-224.

Lee, D.W. \& J.H. Richards 1991. Heteroblastic development in vines. In: F.E. Putz, \& H.A. Mooney, (eds.) The biology of vines, Cambridge University Press, p. 205-244.

LePage, B.A.; Beauchamp, B.; Pfefferkorn, H.W. \& Utting, J.2003. Late Permian plant fossils from the Canadian high arctic: a rare paleoenvironmental/climatic window in northwest Pangea. Palaeogeography, Palaeoclimatolgy, Palaeoecology, 191:345372.

Li, H. \& Taylor, D.W. 1998. Aculeovinea yunguiensis gen. et sp. nov., a new taxon of gigantopterid axis from the Upper Permian of Guizhou province, China. International Journal of Plant Sciences, 159:1023-1033.

Li, H. \& Taylor, D.W. 1999. Vessel-bearing stems of Vasovinea tianii gen. et sp. nov. (Glossopteridales) from the Upper Permian of Guizhou Province, China. American Journal of Botany, 86(11):1563-1575.

Li, H.; Tian, B.; Taylor, E.L. \& Taylor, T.N. 1994. Foliar anatomy of Gigantonoclea guizhouensis (Gigantopteridales) from the Upper Permian of Guizhou Province, China. American Journal of Botany, 81(6):678-689.

Londre, R.A. \& Schnitzer, S.A. 2006. The distribution of lianas and their change in abundance in temperate forests over the past 45 years. Ecology, 87(12):2973-2978.

Looy, C.V.; Brugman, W.A.; Dilcher, D.L. \& Visscher, H. 1999. The delayed resurgence of equatorial forests after the PermianTriassic ecological crisis. Proceedings of the National Academy of Sciences of the United States of America, 96(24):13857-13862.

Lott, E.J.; Bullock, S.H. \& Solis-Magallanes, J.A. 1987. Floristic diversity and structure of upland and arroyo forests of coastal Jalisco. Biotropica, 19(3):228-235.

Masselter, T.; Speck, T. \& Rowe, N.P. 2006. Ontogenetic reconstruction of the Carboniferous seed plant Lyginopteris oldhamia. International Journal of Plant Sciences, 167(1):147166.

McElwain, J.C.; Willis, K.J. \& Lupia, R. 2005. Cretaceous $\mathrm{CO}_{2}$ decline and the radiation and diversification of angiosperms. In: J.R. Ehleringer; T.E. Cerling \& M.D. Dearing (eds.) A history of atmospheric $\mathrm{CO}_{2}$ and its effects on plants, animals and ecosystems. Springer, p. 133-165.

McElwain, J.C.; Popa, M.E.; Hesselbo, S.P.; Haworth, M. \& Surlyk, F. 2007. Macroecological responses of terrestrial vegetation to climatic and atmospheric change across the Triassic/Jurassic boundary in East Greenland. Paleobiology, 33(4):547-573.
McIver, E.E. \& Basinger, J.F. 1999. Early Tertiary floral evolution in the Canadian high arctic. Annals of the Missouri Botanical Garden, 86:523-545.

Menninger, E.A. 1970. Flowering vines of the world: an encyclopedia of climbing plants. New York, Hearthside Press, $410 \mathrm{p}$.

Mohan, J.E.; Ziska, L.H.; Schlesinger, W.H.; Thomas, R.B.; Sicher, R.C.; George, K. \& Clark, J.S. 2006. Biomass and toxicity responses of poison ivy (Toxicodendron radicans) to elevated atmospheric CO2. Proceedings of the National Academy of Sciences (USA), 103:9086-9089.

Mosbrugger, V. \& Roth, A. 1996. Biomechanics in fossil plant biology. Review of Palaeobotany and Palynology, 90:195-207.

Niklas, K.J.; Tiffney, B.H. \& Knoll, A.H. 1983. Patterns in vascular land plant diversification. Nature, 303:614-616.

Niklas, K.J.; Tiffney, B.H. \& Knoll, A.H. 1985. Patterns in vascular land plant diversification: an analysis at the species level. In: J.W. Valentine (ed.) Phanerozoic diversity patterns: profiles in macroevolution, Princeton University Press, p. 97-128.

Opluštil, S.; Pšenièka, J.; Libertin, M. \& Šimùnek, Z. 2007. Vegetation patterns of Westphalian and Lower Stephanian mire assemblages preserved in tuff beds of the continental basins of Czech republic. Review of Palaeobotany and Palynology, 143:107-154.

Opluštil, S.; Pšenièka, J.; Libertín, M.; Bashforth, A.R.; Šimùnek, Z.; Drábková, J. \& Dašková, J. 2009. A Middle Pennsylvanian (Bolsovian) peat-forming forest preserved in situ in volcanic ash: the Whetstone Horizon in the Radnice Basin, Czech Republic. Review of Palaeobotany and Palynology, 155:234274.

Parren, M.P.E.; Bongers, F.; Caballé, G.; Nabe-Nielsen, J. \& Schnitzer, S.A. 2005. On censusing lianas: a review of common methodologies. In: F. Bongers; M.P.E. Parren \& D. Traoré (eds.) Forest Climbing Plants of West Africa, Diversity, Ecology and Management, CABI Publishing, p. 41-58.

Perez-Salicrup, D.R.; Sork, V.L. \& Putz, F.E. 2001. Lianas and trees in a liana forest of Amazonian Bolivia. Biotropica, 33:3447.

Phillips, O.L.; Martínez, R.V.; Mendoza, A.M.; Baker, T.R. \& Vargas, P.N. 2005. Large lianas as hyperdynamic elements of the tropical forest canopy. Ecology, 86(5):1250-1258.

Phillips, O.L.; Martínez, R.V.; Arroyo, L.; Baker, T.R.; Killeen, T.; Lewis, S.L.; Malhi, Y.; Mendoza, A.M.; Neill, D.; Vargas, P.N.; Alexiades, M.; Cerón, C.; Di Fiore, A.; Erwin, T.; Jardim, A.; Palacios, W.; Saldias, M. \& Vinceti, B. 2008. Increasing dominance of large lianas in Amazonian forests. Nature, 418:770-773.

Phillips, T.L. 1981. Stratigraphic occurrences and vegetational patterns of Pennsylvanian pteridosperms in Euramerican coal swamps. Review of Palaeobotany and Palynology, 32:5-26.

Putz, F.E. 1983. Liana biomass and leaf area of a "tierra firme" forest in the Rio Negro Basin, Venezuela. Biotropica, 15(3):185189.

Putz, F.E. \& Holbrook, N.M. 1991. Biomechanical studies of vines. In: F.E. Putz, \& H.A. Mooney (eds.) The biology of vines, Cambridge University Press, p. 73-97.

Putz, F.E. \& Mooney, H.A. (eds.) 1991. The Biology of Vines. New York, Cambridge University Press, 526 p.

Raup, D.M. 1979. Biases in the fossil record of species and genera. Bulletin Carnegie Museum of Natural History, 13:85-91.

Ray, T.S. 1986. Growth correlations within the segment in the Araceae. American Journal of Botany, 73(7):993-1001. 
Rees, P.M. 2002. Land-plant diversity and the end-Permian mass extinction. Geology, 30(9):827-830.

Rees, P.M.; Zeigler, A.M.; Gibbs, M.T.; Kutzbach, J.E.; Behling, P.J. \& Rowley, D.B. 2002. Permian phytogeographic patterns and climate data/model comparisons. Journal of Geology, 110:131.

Richards, P.W. 1996. The tropical rain forest: an ecological study. $2^{\text {nd }}$ ed. Cambridge, Cambridge University Press, 575 p.

Romero-Saltos, H.S. 1999. Diversidad, análisis estrutural y aspectos floristicos relevantes de las lianas en una parcela de bosque muy húmedo premontano, Amazonía ecuatoriana. Pontificia Universidad Católica del Ecuador, Tesis del titulo de Licenciado en Ciencias Biológicas, 103 p.

Schnitzer, S.A. \& F. Bongers 2002. The ecology of lianas and their role in forests. Trends in Ecology and Evolution, 17(5):223230.

Schnitzer, S.A. \& Bongers, F. 2005. Lianas and gap-phase regeneration: implications for forest dynamics and species diversity, In: F. Bongers; M.P.E. Parren \& D. Traoré (eds.) Forest Climbing Plants of West Africa, Diversity, Ecology and Management, CABI Publishing, p. 59-72.

Schnitzer, S.A \& Carson, W.P. 2001. Treefall gaps and the maintenance of species diversity in a tropical forest. Ecology, 82(4):913-919.

Schnitzer, S.A.; Dalling, J.W. \& Carson, W.P. 2000. The impact of lianas on tree regeneration in tropical forest canopy gaps: evidence for an alternative pathway of gap-phase regeneration. Journal of Ecology, 88:655-666.

Selaya, N.G. \& Anten, N.P.R. 2008. Differences in biomass allocation, light interception and mechanical stability between lianas and trees in early secondary tropical forest. Functional Ecology, 22:30-39.

Skog, J.R. 2001. Biogeography of Mesozoic leptosporangiate ferns related to extant ferns. Brittonia, 53(2):236-269.

Smith, A.R.; Pryer, K.M.; Schuettpelz, E.; Korall, P.; Schneider, H. \& Wolf, P.G. 2006. A classification for extant ferns. Taxon, 55(3):705-731.

Speck, T. 1994. A biomechanical method to distinguish between self-supporting and non-self supporting fossil plants. Review of Palaeobotany and Palynology, 81:65-82.

Stevens, L.G. \& Hilton, J. 2009. Ontogeny and ecology of the Filicalean fern Oligocarpia gothanii (Gleicheniaceae) from the Middle Permian of China. American Journal of Botany, 96(2):475-486.

Taylor, T.N. \& Millay, M.A. 1981. Morphologic variability of Pennsylvanian lyginopterid seed ferns. Review of Palaeobotany and Palynology, 32:27-62.

Taylor, T.N.; Taylor, E.L. \& Krings, M. 2009. Paleobotany: the biology and evolution of fossil plants. Boston, Academic Press/ Elsevier, $1230 \mathrm{p}$.

Teramura, A.H.; Gold, W.G. \& Forseth, I.N. 1991. Physiological ecology of mesic, temperate woody vines. In: F.E. Putz \& H.A. Mooney (eds.) The biology of vines, Cambridge University Press, p. 245-285.

Tomescu, A.M.F.; Rothwell, G.W. \& Mapes, G. 2001. Lyginopteris royalii sp. nov. from the Upper Mississippian of North America. Review of Palaeobotany and Palynology, 116(3-4):159-173.

Walton, J. 1923. On Rhexoxylon Bancroft - a Triassic genus of plants exhibiting a liane-type of vascular organisation. Philosophical Transactions of the Royal Society B, 212:79-109

Wang, Y. 2002. Fern ecological implications from the lower Jurassic in Western Hubei, China. Review of Palaeobotany and Palynology, 119:125-141.

Wang, Z.-Q. 1999. Gigantonoclea: an enigmatic Permian plant from north China. Palaeontology, 42(2):329-373.

Willis, K.J. \& McElwain, J.C. 2002. The Evolution of Plants. Oxford, Oxford University Press, 378 p.

Wing, S.L. \& DiMichele, W.A. 1995 Conflict between local and global changes in plant diversity through geological time. Palaios, 10:551-564.

Wright, S.J.; Calderón, O.; Hernandéz, A. \& Paton, S. 2004. Are lianas increasing in importance in tropical forests? A 17-year record from Panama. Ecology, 85(2):484-489.

Zeiller, R. 1906. Bassin houiller et permien de Blanzy et du Creusot II. Flore fossile. Paris, Études des gîtes minéraux de la France, $265 \mathrm{p}$.

Received in February, 2009; accepted in July, 2009. 